\title{
Association of allelic polymorphisms of the Matrix Gla-protein system genes with acute coronary syndrome in the Ukrainian population
}

\author{
V. Yu. Garbuzova ${ }^{1}$, D. A. Stroy ${ }^{2}$, V. E. Dosenko², O. A. Obukhova ${ }^{1}$, O. V. Ataman ${ }^{1}$ \\ ${ }^{1}$ Sumy State University \\ 2, Rymskogo-Korsakova Str., Sumy, Ukraine, 40007; \\ 2 Bogomoletz Institute of Physiology, NAS of Ukraine \\ 4, Bogomoletz Str., Kyiv, Ukraine, 01024 \\ vikgarbuzova@yandex.ru
}

\begin{abstract}
Calcification of the vascular wall is a prognostic factor for the outcome of acute coronary syndrome (ACS). Matrix Gla-protein system, which includes MGP, VDR, VKOR, GGCX, BMP-2 is an important factor in vessels protection of ectopic calcification. Polymorphisms of genes, which encode the structure of these proteins, determine their activity and may affect the intensity of calcification and the consequences of ACS. Aim. The association between ACS and polymorphic variants of Matrix Gla-protein system genes: $M G P$ (rs1800802, rs1800801, rs4236), VDR (rs2228570, rs1544410, rs7975232, rs731236), GGCX (rs699664), VKORC1 (rs2359612), BMP-2 (rs2273073), was analyzed. Methods. Venous blood of 118 patients with ACS and 234 healthy individuals (control group) was used for genotyping. Polymorphisms of Matrix Glaprotein system genes were examined by PCR-RFLP methodology. Results. The risk of ACS in carriers of minor allele $A / A$ (rs1800801) is 2.8 times higher; G/G (rs1544410) 2.1 times higher; A (rs699664) and C (rs2359612) 2 times higher than in carriers of the major allele. The best classification model is a two-component model that includes polymorphisms rs 1800801 and rs4236 of the MGP gene (predictive ability is 63 $\%$ for MDR and $68 \%$ for the Random forest method). The coincidence of similar orientation genotype variants for chosen polymorphism[s] was associated with a high risk of developing ACS: in the heterozygote genotype it increased by 2.1 times, and in the homozygote for the minor allele genotype, by 6.3 times. Conclusion. There is an association between ACS and some polymorphic variants of Matrix Gla-protein system genes: $M G P$ (rs1800801), VDR (rs1544410), GGCX (rs699664), VKORCl (rs2359612). This indicates a higher risk of complications in the ACS patients with the following genotypes: $A / A$ (rs1800801), $G / G$ (rs1544410), $A / A$ (rs699664) and $C / C(\mathrm{rs} 2359612)$.
\end{abstract}

Ke y w ord s: acute coronary syndrome, allelic polymorphism, matrix Gla-protein.

\section{Introduction}

Vascular calcification has a pivotal role among the factors which relate to the complications of atherosclerosis, including acute coronary syndrome, that can occur either in the intima (mineralization of atherosclerotic plaques) or in the middle layer of the vascular wall (Mönckeberg's sclerosis) [1-4]. The deposition of calcium phosphate crystals in arteries structure, according to many authors, is a poor prognostic factor that indicates a high probability of fatal complications [5-7]. The matrix Gla-protein plays an important role in the vessel protection against ectopic calcification; its presence in tissues prevents initiation and spread of a pathological calcification [8-11]. A large number of studies managed to find the factors involved in the regulation of the $M G P$ gene expression, and identified possible mechanisms, through which the corresponding protein realizes its anti-calcification properties. It gave a reason to talk of the Matrix Gla-protein functional system that yields, except for the matrix Gla-protein,

(C) 2015 V. Yu. Garbuzova et al.; Published by the Institute of Molecular Biology and Genetics, NAS of Ukraine on behalf of Biopolymers and Cell. This is an Open Access article distributed under the terms of the Creative Commons Attribution License (http://creativecommons.org/licenses/by/4.0/), which permits unrestricted reuse, distribution, and reproduction in any medium, provided the original work is properly cited 
such factors as vitamin D receptor (VDR), the enzymes involved in biochemical transformations of the matrix Gla-protein, vitamin $\mathrm{K}$ epoxide reductase (VKOR) and vitamin K-dependent gamma-glutamyl carboxylase (GGCX), as well as potential targets for the matrix Gla-protein, including bone morphogenetic protein-2 (BMP-2) (Fig. 1). The effective operation of the system may depend on many factors, including gene polymorphisms that encode corresponding protein structures.

Today the connection between the different $M G P$ gene allelic variants and the cardiovascular diseases (atherosclerosis, myocardial infarction, heart stroke) [12-18], osteoporosis [19-20], urolithiasis [21], tooth loss [22], plumbum intoxication [23-24] is studied. The published data on this subject are ambiguous and contradictory. The comprehensive studies on the role of genetic polymorphism of $M G P$ and related genes in the development of cardiovascular diseases have not been carried out yet. Therefore, the purpose of this study was to explore the allele's frequency of polymorphisms of Matrix Gla- protein system genes ( $M G P, V D R, V K O R C 1, G G C X$, $B M P-2)$ in patients with acute coronary syndrome in the Ukrainian population and to analyze the complex influence of studied polymorphisms on the disease development.

\section{Materials and methods}

\section{Study subjects}

118 patients ( $81.7 \%$ males and $18.0 \%$ females) with ACS aged between 40 and 83 (mean age $58.5 \pm 0.7$ years) were included into the study. Participants of the study were admitted to the hospital to the reanimation and intensive therapy department of National Scientific Center «M.D. Strazhesko Institute of Cardiology», National Medical Academy of Science, Ukraine. Unstable angina pectoris (UAP) and acute myocardial infarction (MI) as a final diagnosis were established in $33.5 \%$ and $66.5 \%$ of patients, respectively. Diagnosis of acute MI and UAP was established on the basis of clinical, electrocardiography and biochemical examinations according to the rec-

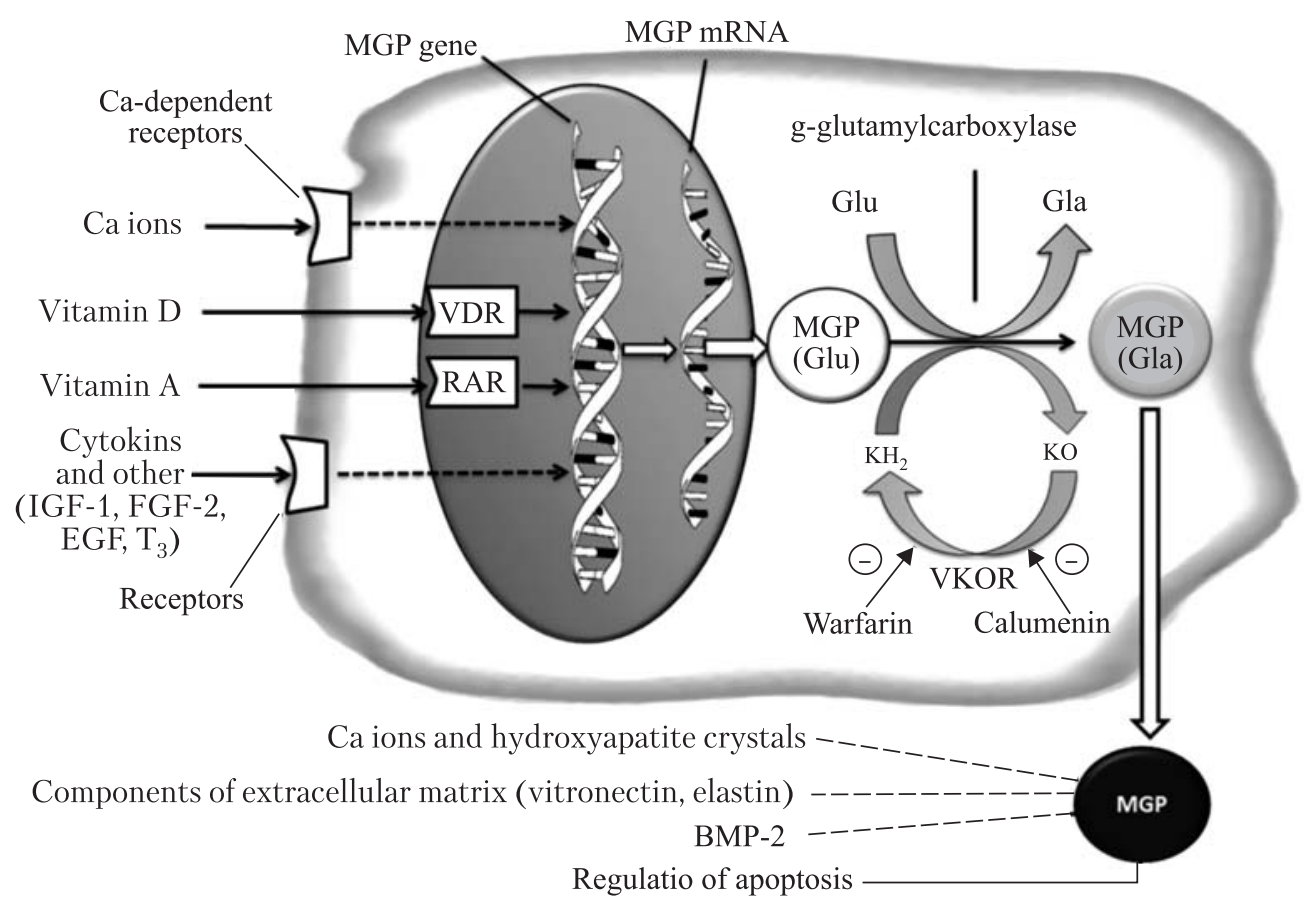

Fig. 1. The main components of the process that ensures the functioning of the matrix Gla-protein in tissues 
ommendations of WHO experts and the recommendations of European and American cardiologic societies [25-26].

The control group consisted of 234 clinically healthy individuals. The absence of cardio-vascular pathologies was confirmed by anamnesis, ECG examination, measurement of arterial pressure and biochemical data. The group of healthy individuals and patients with ACS differed in the ratio of men and women $(\mathrm{P}=0.034)$, the average age in the first group $(66.0 \pm 0.95$ years $)$ was significantly higher than in the second group $(\mathrm{P}<0.001)$ (Table 1$)$. The significantly higher average age in the control group contributes to the reliability of selection procedure, ex- cluding the influence of age as a risk factor for acute coronary syndrome development.

\section{Amplification and genotyping}

Blood sampling was performed under sterile conditions in $2.7 \mathrm{ml}$ monovettes containing EDTA potassium salt $(11.7 \mathrm{mM})$ as an anticoagulant (Sarstedt, Germany), sample were frozen and stored at $-20{ }^{\circ} \mathrm{C}$. DNA for genotyping was extracted from the samples using Isogene kits (Russian Federation) according to manufacturer's protocol. 10 polymorphisms were studied (Table 2).

In the present study, a polymerase chain reaction with subsequent analysis of restriction fragment

Table 1. General clinical characteristics of patients with ACS and control subjects

\begin{tabular}{|l|c|c|c|}
\hline \multicolumn{1}{|c|}{ Parameter } & $\begin{array}{c}\text { Control group } \\
(\mathrm{n}=234)\end{array}$ & $\begin{array}{c}\text { ACS group } \\
(\mathrm{n}=118)\end{array}$ & P \\
\hline Sex, female/male & $77 / 157(32.9 \% / 67.1 \%)$ & $26 / 92(22 \% / 78 \%)$ & $0.034^{*}$ \\
Age, years & $66.0 \pm 0.95$ & $55.9 \pm 0.89$ & $<0.001$ \\
BMI (f), $\mathrm{kg} / \mathrm{m}^{2}$ & $28.6 \pm 0.13$ & $31.5 \pm 0.9$ & 0.013 \\
BMI (m) $\mathrm{kg} / \mathrm{m}^{2}$ & $26.8 \pm 0.34$ & $27.6 \pm 0.42$ & 0.141 \\
SBP, $\mathrm{mm} \mathrm{Hg}$ & $139.5 \pm 1.5$ & $140.8 \pm 1.7$ & $<32$ \\
DBP, $\mathrm{mm} \mathrm{Hg}$ & $83.4 \pm 0.7$ & $89.5 \pm 0.9$ & $<0.001$ \\
Glucose, $\mathrm{mmol} / \mathrm{L}$ & $5.27 \pm 0.05$ & $7.9 \pm 0.24$ & $<0.001$ \\
Current smokers, \% & $60(25.6 \%)$ & $54(45.8 \%)$ & $0.001^{*}$ \\
Stressful profession, \% & $65(27.8 \%)$ & $49(41.5 \%)$ & $0.009 *$ \\
\hline
\end{tabular}

Note: $\mathrm{P}$ - for Student t-test, ${ }^{*} \mathrm{P}-$ for $\chi^{2}$-criterion

Table 2. The studied polymorphisms of the Matrix Gla-protein system genes

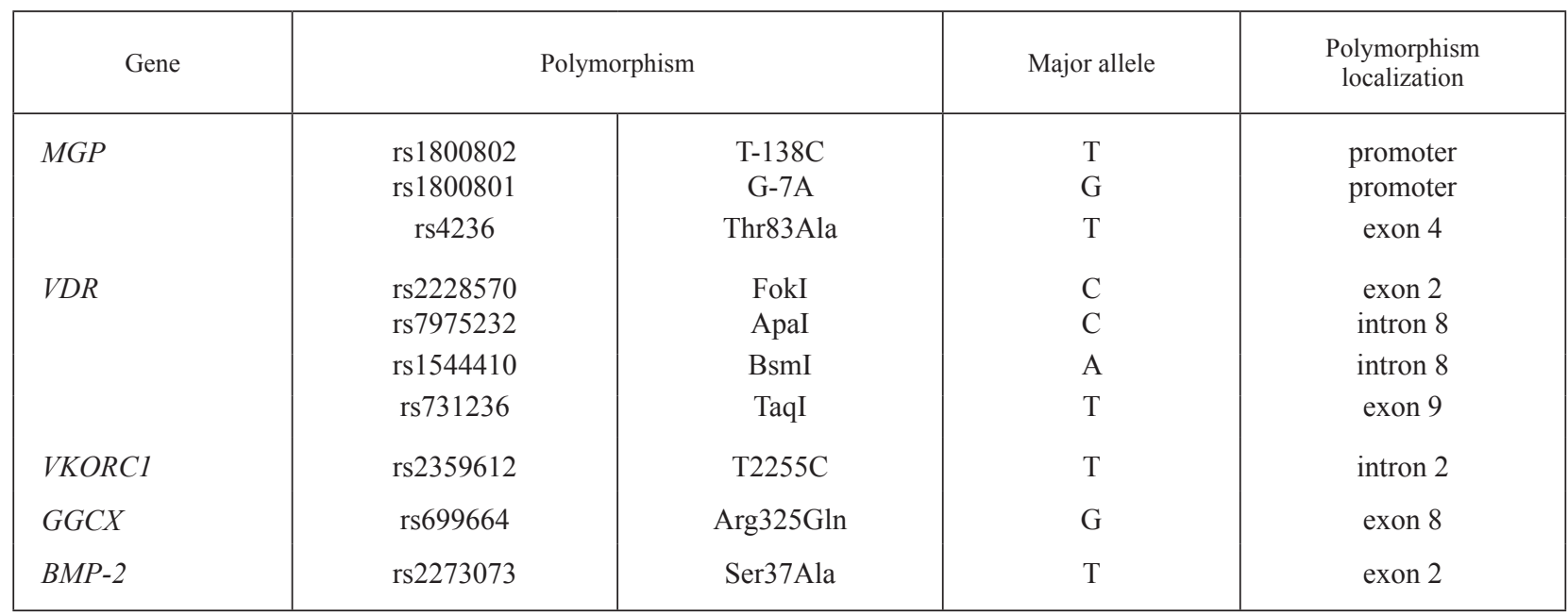


Table 3. Details of PCR and RFLP for polymorphism analysis

\begin{tabular}{|c|c|c|c|c|c|}
\hline Polymorphisms & Primers & $\begin{array}{c}\text { Annealing } \\
\text { temperature, } \\
{ }^{\circ} \mathrm{C} / \text { Time, s }\end{array}$ & $\begin{array}{c}\text { PCR } \\
\text { product size } \\
(\mathrm{bp})\end{array}$ & $\begin{array}{l}\text { Restriction } \\
\text { enzymes }\end{array}$ & $\begin{array}{l}\text { Fragments } \\
\text { after } \\
\text { restriction }\end{array}$ \\
\hline $\begin{array}{l}M G P, \mathrm{~T}-138 \mathrm{C} \\
(\mathrm{rs} 1800802)\end{array}$ & $\begin{array}{l}\text { F: } 5^{`} \text {-AAGCATACGATGGCCAAAACTTCTGCA-3` } \\
\text { R: } 5^{`} \text {-GAACTAGCATTGGAACTTTTCCCAACC-3` }\end{array}$ & $57 / 60$ & 142 & BseNI & 118,24 \\
\hline $\begin{array}{l}M G P, \mathrm{G}-7 \mathrm{~A} \\
\text { (rs 1800801) }\end{array}$ & $\begin{array}{l}\text { F: } 5 \text { `-CTAGTTCAGTGCCAACCCTTCCCCACC-3` } \\
\text { R: } 5 \text { '-TAGCAGCAGTAGGGAGAGAGGCTCCCA-3` }\end{array}$ & $64.5 / 45$ & 500 & NcoI & 240,260 \\
\hline $\begin{array}{l}M G P, \text { Thr83Ala } \\
\text { (rs 4236) }\end{array}$ & $\begin{array}{l}\text { F: } 5^{`} \text {-TCAATAGGGAAGCCTGTGATG-3`' } \\
\text { R: } 5 \text { '-AGGGGG ATACAAAATCAGGTG-3` }\end{array}$ & $64.5 / 45$ & 173 & Eco47I & 127,46 \\
\hline $\begin{array}{l}V D R, \text { FokI } \\
(\text { rs 2228570) }\end{array}$ & $\begin{array}{l}\text { F: } 5^{`} \text {-AGCTGGCCCTGGCACTGACTCTG-3' } \\
\text { R: } 5 \text { '-ATGGAAACACCTTGCTTCTTCTCCCTC-3` }\end{array}$ & $64.5 / 45$ & 267 & FokI & 204,63 \\
\hline $\begin{array}{l}V D R, \text { BsmI } \\
\text { (rs 1544410) }\end{array}$ & $\begin{array}{l}\text { F: } 5^{`} \text {-AGGGAGACGTAGCAAAAGGAG-3’ } \\
\text { R: } 5^{`} \text {-TGTCCCCAAGGTCACAATAAC-3`' }\end{array}$ & $60 / 45$ & 425 & BsmI & 232,193 \\
\hline $\begin{array}{l}V D R, \text { ApaI } \\
\text { (rs 7975232) }\end{array}$ & $\begin{array}{l}\text { F: } 5^{`} \text {-CAGAGCATGGACAGGGAGCAA-3` } \\
\text { R: } 5^{`} \text {-CACTTCGAGCACAAGGGGCGTTAGC-3` }\end{array}$ & $64.5 / 45$ & 501 & ApaI & 284,217 \\
\hline $\begin{array}{l}V D R, \text { TaqI } \\
\text { (rs 731236) }\end{array}$ & $\begin{array}{l}\text { F: } 5^{`} \text {-CAGAGCATGGACAGGGAGCAA-3` } \\
\text { R: } 5 \text { 'CACTTCGAGCACAAGGGGCGTTAGC-3` }\end{array}$ & $64.5 / 45$ & 501 & TaqI & 294,207 \\
\hline $\begin{array}{l}G G C X, \operatorname{Arg} 325 \mathrm{Gln} \\
\text { (rs 699664) }\end{array}$ & $\begin{array}{l}\text { F: } 5^{`} \text {-GGAGAAGTCTCCTAAGGGAACG-3` } \\
\text { R: } 5^{\prime} \text {-AGTC CAGCCTTTGCTGTACACT -3`' }\end{array}$ & $65 / 30$ & 384 & $X m n \mathrm{I}$ & 216,168 \\
\hline $\begin{array}{l}\text { VKORC1, T2255C } \\
(\text { rs 2359612) }\end{array}$ & $\begin{array}{l}\text { F: 5'-GAACAGAGAGAGGAACCAAGGGAGTGGA-3' } \\
\text { R: 5'-TCTGAACCATGTGTCAGCCAGGACC-3' }\end{array}$ & $62.5 / 45$ & 198 & NcoI & 172,26 \\
\hline $\begin{array}{l}B M P-2, \text { Ser37Ala } \\
\text { (rs 2273073) }\end{array}$ & $\begin{array}{l}\text { F: 5'-CTCACGTCGGTCCTGTC C-3' } \\
\text { R: 5'-CCCTGCTCCATGCCTCAC-3' }\end{array}$ & $60 / 60$ & 393 & Нpy99I & 253,140 \\
\hline
\end{tabular}

Table 4. The distribution of genotypes by the polymorphisms of Matrix Gla-protein system genes in patients with ACS and control group

\begin{tabular}{|l|c|c|c|}
\hline \multicolumn{1}{|c|}{ Genotype } & $\begin{array}{c}\text { ACS group } \\
(1 / 1: 1 / 2: 2 / 2)(\%)\end{array}$ & $\begin{array}{c}\text { Control group } \\
(1 / 1: 1 / 2: 2 / 2)(\%)\end{array}$ & $\mathrm{P}$ \\
\hline$M G P$, rs1800802 & $59.3: 33.1: 7.6$ & $59.4: 35.9: 4.7$ & 0.506 \\
$M G P$, rs1800801 & $41.5: 45.8: 12.7$ & $50.4: 44.0: 5.6$ & 0.040 \\
$M G P$, rs4236 & $43.2: 42.4: 14.4$ & $38.9: 49.6: 11.5$ & 0.418 \\
$V D R$, rs2228570 & $27.1: 51.7: 21.2$ & $28.6: 49.1: 22.3$ & 0.903 \\
$V D R$, rs1544410 & $37.3: 44.1: 18.6$ & $44.9: 44.4: 10.7$ & 0.091 \\
$V D R$, rs7975232 & $28.8: 49.2: 22$ & $32.9: 43.6: 23.5$ & 0.521 \\
$V D R$, rs731236 & $37.3: 48.3: 14.4$ & $44.0: 46.2: 9.8$ & 0.305 \\
$G G C X$, rs699664 & $27.1: 52.5: 20.4$ & $35.0: 52.2: 12.8$ & 0.110 \\
$V K O R C 1$, rs2359612 & $27.1: 41.5: 31.4$ & $37.2: 42.7: 20.1$ & 0.038 \\
$B M P-2$, rs2273073 & $50.0: 32.2: 17.8$ & $45.3: 40.2: 14.5$ & 0.327 \\
\hline
\end{tabular}

Note: 1/1 1/2 2/2 — ratio for major allele homozygotes to heterozygotes and to homozygotes for the minor allele, $\mathrm{P}$ - an indicator of the significance of differences in distribution of genotypes between the ACS group and control groups. 
length (PCR-RFLP) was used for genotyping a single nucleotide polymorphism (Table 3 ). Primers were synthesized by «Metabion» (Germany), and enzymes (Taq-polymerase, and restriction enzyme) from «Thermo Scientific» (USA).

PCR was performed in a thermocycler Gene Amp PCR System 2700 («Applied Biosystems», USA). Restriction products were separated in $2.5 \%$ agarose gel containing etidium bromide, which formed a stable compound with DNA fragments, visualized as stripes in the UV-illuminated gel with the transilluminator UVT-a Biocom (Russian Federation).

\section{Statistical analysis}

The normal distribution and homogeneity of variances were tested before further statistical analyses. The distribution of genotypes of studied SNPs was analyzed using the Pearson's chi-square test. Statistically significant results were presented by the corresponding exact P-values. Statistical significance of differ-

Table 5. Analysis of ACS risk that depends on G-7A polymorphism genotype of MGP gene in females and males

\begin{tabular}{|l|c|c|c|c|c|c|c|}
\hline \multicolumn{1}{|c|}{ Group } & CR & SE & WS & P & OR & $\begin{array}{c}\text { 95 \% CI for } \\
\text { OR lower }\end{array}$ & $\begin{array}{c}\text { 95\% CI for } \\
\text { OR higher }\end{array}$ \\
\hline General & 1.022 & 0.415 & 6.056 & 0.014 & 2.779 & 1.231 & 6.271 \\
Females & 1.718 & 0.708 & 5.879 & 0.015 & 5.571 & 1.390 & 22.334 \\
Males & 0.883 & 0.539 & 2.685 & 0.101 & 2.418 & 0.841 & 6.954 \\
\hline
\end{tabular}

Note: homozygotes for the minor allele (A/A) are compared with carriers of the principal allele $(\mathrm{G} / \mathrm{A}+\mathrm{G} / \mathrm{G})$; CR - regression coefficient; SE - standard error; WS - Wald statistics; P - statistical significance; OR - odds ratio ; CI - confidence interval

Table 6. Analysis of ACS risk associated with variation in genes of Matrix Gla-protein system

\begin{tabular}{|c|c|c|c|c|c|c|}
\hline $\begin{array}{c}\text { Gene, } \\
\text { polymorphism }\end{array}$ & Genotype & $\begin{array}{l}\text { Control, } \\
\text { n (\%) }\end{array}$ & $\begin{array}{c}\text { ACS group, } \\
\text { n (\%) }\end{array}$ & OR & p-value & $\begin{array}{l}\text { The best } \\
\text { model* }\end{array}$ \\
\hline \multirow[t]{2}{*}{$M G P, \operatorname{rs} 1800802$} & $\mathrm{~T} / \mathrm{T}+\mathrm{T} / \mathrm{C}$ & $223(95.3)$ & $109(92.4)$ & & & $\mathrm{R}$ \\
\hline & $\mathrm{C} / \mathrm{C}$ & $11(4.7)$ & $9(7.6)$ & $1.67(0.66-4.16)$ & 0.27 & \\
\hline \multirow[t]{2}{*}{$M G P, \operatorname{rs} 1800801$} & $\mathrm{G} / \mathrm{G}+\mathrm{G} / \mathrm{A}$ & $221(94.4)$ & $103(87.3)$ & & & $\mathrm{R}$ \\
\hline & $\mathrm{A} / \mathrm{A}$ & $13(5.6)$ & $15(12.7)$ & $2.48(1.14-5.47)$ & 0.02 & \\
\hline \multirow[t]{2}{*}{$M G P, \mathrm{rs} 4236$} & $\mathrm{~T} / \mathrm{T}+\mathrm{C} / \mathrm{C}$ & $118(50.4)$ & $68(57.6)$ & & & $\mathrm{O}$ \\
\hline & $\mathrm{T} / \mathrm{C}$ & $116(49.6)$ & $50(42.4)$ & $0.75(0.48-1.17)$ & 0.2 & \\
\hline \multirow[t]{2}{*}{$V D R$, rs 2228570} & $\mathrm{C} / \mathrm{C}+\mathrm{T} / \mathrm{T}$ & $119(50.9)$ & $57(48.3)$ & & & $\mathrm{O}$ \\
\hline & $\mathrm{C} / \mathrm{T}$ & $115(49.1)$ & $61(51.7)$ & $1.11(0.71-1.73)$ & 0.65 & \\
\hline \multirow[t]{2}{*}{$V D R$, rs 7975232} & $\mathrm{C} / \mathrm{C}+\mathrm{A} / \mathrm{A}$ & $132(56.4)$ & $60(50.8)$ & & & $\mathrm{O}$ \\
\hline & $\mathrm{C} / \mathrm{A}$ & $102(43.6)$ & $58(49.2)$ & $1.25(0.8-1.95)$ & 0.32 & \\
\hline \multirow[t]{2}{*}{$V D R, \operatorname{rs} 1544410$} & $\mathrm{~A} / \mathrm{A}+\mathrm{A} / \mathrm{G}$ & 209 (89.3) & $95(80.5)$ & & & $\mathrm{R}$ \\
\hline & $\mathrm{G} / \mathrm{G}$ & $25(10.7)$ & $23(19.5)$ & $2.02(1.09-3.75)$ & 0.02 & \\
\hline \multirow[t]{2}{*}{$V D R, \operatorname{rs} 731236$} & $\mathrm{~T} / \mathrm{T}$ & - & - & & & A \\
\hline & $2 \mathrm{C} / \mathrm{C}+\mathrm{T} / \mathrm{C}$ & - & - & $1.29(0.93-1.8)$ & 0.13 & \\
\hline \multirow{2}{*}{ VKORC1, rs2359612 } & $\mathrm{T} / \mathrm{T}$ & - & - & & & A \\
\hline & $2 \mathrm{C} / \mathrm{C}+\mathrm{T} / \mathrm{C}$ & - & - & $1.46(1.09-1.97)$ & 0.01 & \\
\hline$G G C X, \mathrm{rs} 699664$ & $\begin{array}{c}\mathrm{G} / \mathrm{G} \\
2 \mathrm{~A} / \mathrm{A}+\mathrm{G} / \mathrm{A}\end{array}$ & - & - & $1.43(1.03-2)$ & 0.03 & A \\
\hline \multirow[t]{2}{*}{$B M P-2$, rs 2273073} & $\mathrm{~T} / \mathrm{T}+\mathrm{G} / \mathrm{G}$ & $140(59.8)$ & $80(67.8)$ & & & $\mathrm{O}$ \\
\hline & $\mathrm{T} / \mathrm{G}$ & $94(40.2)$ & $38(32.2)$ & $0.71(0.44-1.12)$ & 0.15 & \\
\hline
\end{tabular}

Note: $\mathrm{O}$ - the best inheritance model is overdominant, $\mathrm{R}$ - the best inheritance model is recessive, $\mathrm{A}$ - the best inheritance model is additive. $*_{-}$the best model has been chosen with the help of AIC (Akaike Information Criteria). 
ence in probability estimates was checked by Student's t-test. In order to predict the risk of acute coronary syndrome the logistic regression was used. The differences were considered statistically significant by $\mathrm{P}$-value $<0.05$. Selection of the main complication predictors of atherosclerosis among the studied polymorphisms was performed with «Random Forest» algorithm [27-29]. Finally, MDR method (multifactor dimensionality reduction) was used for the detection and characterization of interactions between genes [30]. Statistical analyses were performed using the Statistical Package for Social Science program (SPSS for Windows, version 17.0, SPSS Inc., Chicago, IL.)

\section{Results and Discussion}

Genotyping patients with ACS for ten sites of the Matrix Gla-protein system genes and comparison of the data with the results of the restriction analysis in the control group allowed determining the frequency of some variants of these genes (Table 4).

There was a statistically significant difference in distribution of alleles in patients with ACS and healthy individuals only for rs1800801 of $M G P$ gene $(\mathrm{P}=$ $=0.040)$ and for rs2359612 of VKORC1 gene $(\mathrm{P}=$ $=0.038)$. By this means, there was a link between these polymorphisms and the development of ACS. Using a logistic regression confirmed this conclusion: females of A/A genotype (rs1800801) had 5.6 times higher risk to suffer from ACS than carriers of the major allele $(G / A+G / G)$ (Table 5).

To identify a possible association of genetic markers of the disease risk there were used conventional statistical models (codominant, dominant, overdominant, recessive, additive). The best model for each polymorphism was characterized by the lowest Akaike information criterion. The association of SNPs (rs1800801 of MGP gene, rs 1544410 of $V D R$ gene, rs2355612 of VKORC1 gene, rs 699664 of GGCX gene) with ACS was proven (Table 6).

Similar studies in this area are limited and contradictory. For example, the connection between six variants of the $M G P$ gene and the development of myocardial infarction (MI) was analyzed in ECTIM Study (ECTIM Study, Northern Ireland, and France) [16]. It was shown that allele and genotype frequen-

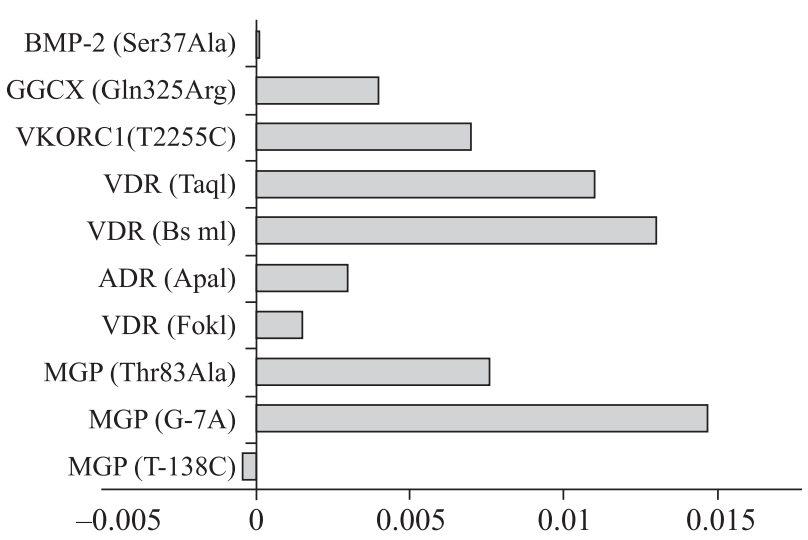

Fig. 2. Predictors of ACS in terms of their value («Random Forest» method)

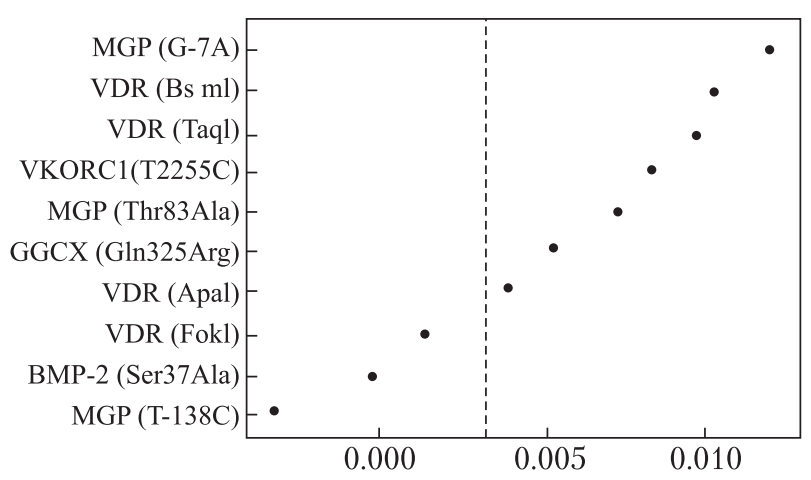

Fig. 3. Results of «noise filter» method. Important predictors are placed to the right of the dotted line

cies were the same for all SNP types in MI patients and in the control group. Only in one subgroup, where patients and control subjects were divided into groups of high and low risk of coronary heart disease, it was found that the frequency of minor alleles $(-7 \mathrm{~A}$ and $83 \mathrm{G})$ in $\mathrm{MI}$ patients with low-risk factors was higher than in the corresponding control subgroup. Ortlepp et al. determined an association between the G/G genotype of VDR gene BsmI polymorphism and the risk of myocardial infarction in patients under the age of 65 [31]. The contradictory data were obtained by Shanker et al. [32] and Pan et al. [33] — they detected no association between polymorphic variants and haplotypes of the VDR gene and the development of coronary heart disease. Porojan et al. examined the relation of $V K O R C 1$ allelic polymorphisms with atherosclerosis and calci- 


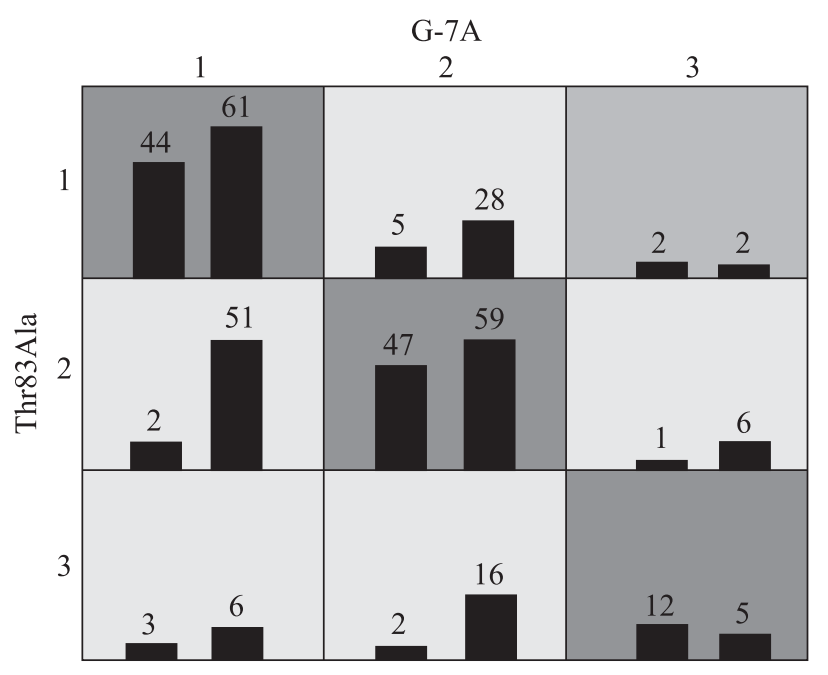

Fig. 4. Display the combination of rs 1800801 and rs4236 genotypes associated with high- and low-risk ACS. Left column within each cell represents the number of cases, right column the number of controls. Dark gray cells correspond to high risk, and light-gray - low risk of ACS

fication. The authors found that a polymorphism of the first intron of the C1173T VKORC1 gene was associated with calcification of the blood vessels and was an important genetic factor in the development of atherosclerosis [34]. Wang et al., studying the distribution of the VKORC1 T2255C polymorphism, found that the presence of the $\mathrm{C}$ allele more than twice increased the risk of coronary heart disease and stroke, and more than three times - the risk of aortic dissection [35]. Nevertheless, Hindorff et al., who studied the association of $V K O R C 1$ gene polymorphisms, including $\mathrm{T} 2255 \mathrm{C}$, with the development of myocardial infarction and other cardiovascular diseases, showed that none of the studied SNPs were associated with the development of diseases of heart and blood vessels [36].

The next step was to study the combined effects of polymorphisms of the Matrix Gla-protein system genes and to clarify their common contribution to the development of ACS. A similar analysis made it possible to identify the most informative combinations of polymorphic loci; in case of its combined effect they had a pivotal role in development of ACS. Random forest was the method of first choice in the algorithm of data analysis. It allowed ranking all the studied polymor- phisms (predictors) according to their importance level (degree of contribution to the development of ACS and the ability to predict the risk of its occurrence). According to this method, rs1800801 of the MGP gene was the most important among all predictors (Fig. 2).

The method of selection of the most significant predictors, proposed by C. Strobl, was used to improve the classification model [29]. This method is based on the principle that randomization importance of the risk factors which have a minor impact on the risk of disease, hovers around zero. According to this method, the absolute value is taken as the factor with the lowest value of randomization and this value becomes a threshold and reference for the vertical line, as all significant predictors have to cross this limit (Fig. 3). Polymorphism rs 1800801 of the MGP gene was confirmed to be the most significant predictor of ACS like in the previous analysis. Only the polymorphic variants located to the right of the dotted line were selected for further study. The classification model with $75 \%$ predictive ability in training sample and $68 \%$ in testing sample was designed on this basis.

Simulation of intergenic interaction of studied polymorphisms implemented by Multifactorial Dimensionality Reduction (MDR) allowed selection of the most pathogenic combinations of polymorphic loci significant for ACS.

Two-loci pattern of rs 1800801 and rs4236 was statistically significant. It had $63 \%$ classification ability with $8 / 10$ cross-validation consistency. MDR method eliminated some of those predictors that were identified by the «noise filtering», whereas the predictive ability of the model decreased by only $4 \%$. The combination of polymorphisms rs 1800801 and rs4236 of the $M G P$ gene is reflected in Fig. 4. It was found that the coincidence of both SNP genotypes is associated with the increased risk of ACS. Attention is drawn to the fact that even the coincidence of two homozygotes for the major allele leads to a significant increase of the risk of ACS. It was found by means of MDR that the largest proportion of entropy (the biggest independent effect) with connection to the status of «case-control» was associated with $\mathrm{rs} 1$ 800801 and rs2359612 loci and was $1.26 \%, 1.33 \%$, respectively (Fig. 5). At the same time an analysis of 


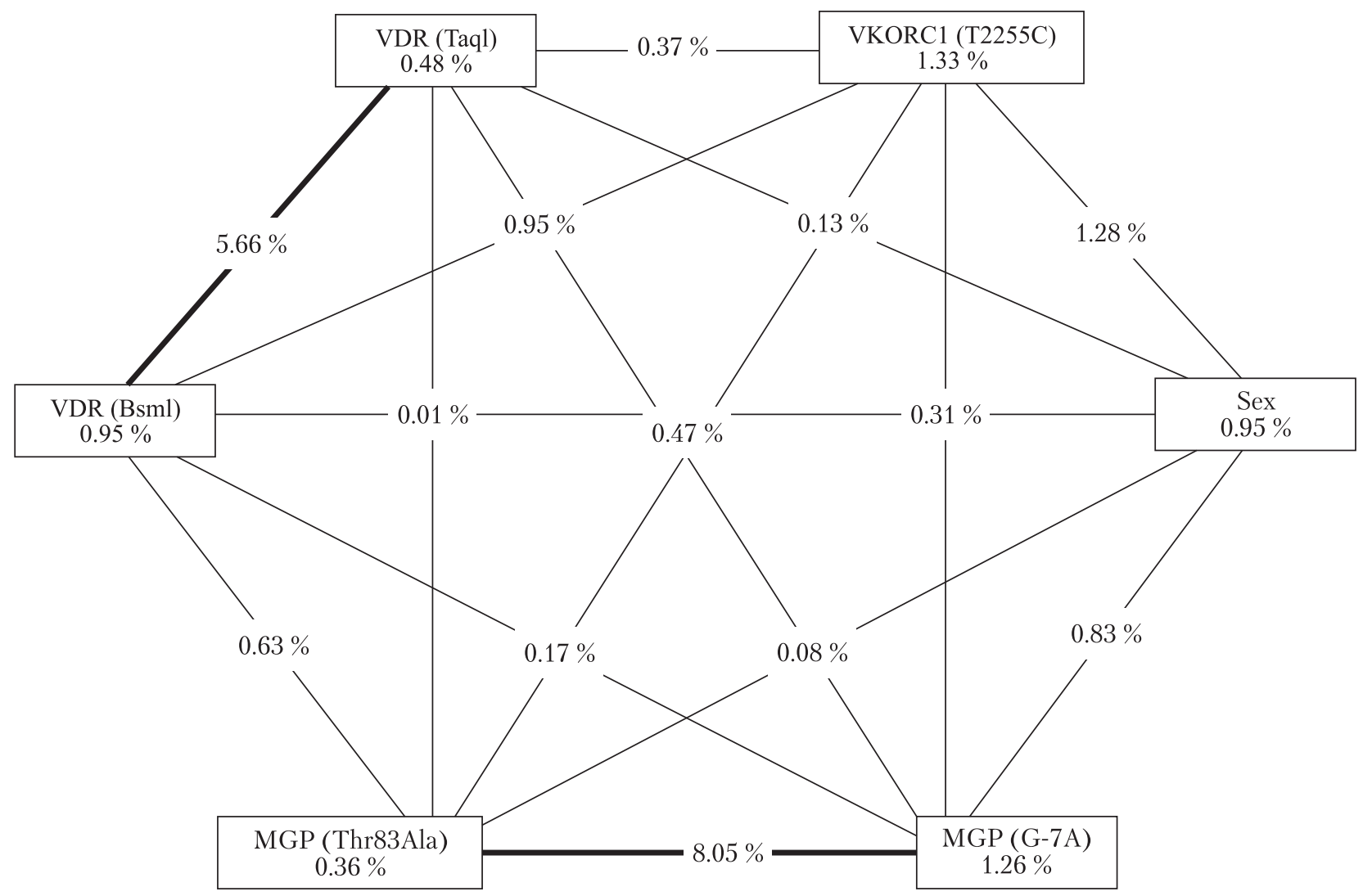

Fig. 5. Diagram of cluster analysis of intergenic interaction results by MDR simulation in ACS group. Synergistic interaction is marked by a bold line, and lack of interaction is marked by a thin line

intergenic interactions revealed that the greatest phenotypic entropy was accounted for the interaction of rs $1800801 \&$ rs4236 loci and it amounted to $8 \%$. It showed a pronounced synergistic effect for both SNPs and once again proved that rs 1800801 was the most important predictor of ACS. The synergy was also observed between polymorphisms rs 731236 and rs 1544410 of $V D R$ gene (5.66\%), although they were not included in the composition of the most informative classification model.

All other polymorphisms showed mainly independent effects. Finally, we applied permutation (randomized) tests, which showed that the two-component model was statistically significant at $\mathrm{p}<0.05$.

In order to confirm our MDR results, the interaction between polymorphisms rs 1800801 and rs4236

Table 7. Analysis of ACS risk, that depends on the polymorphisms rs4236 and rs18008010f MGP gene

\begin{tabular}{|c|c|c|c|c|c|c|c|}
\hline $\begin{array}{c}\text { Genotype } \\
\text { combination }\end{array}$ & CR & SE & WS & P & OR & $\begin{array}{c}95 \% \text { CI for } \\
\text { OR lower }\end{array}$ & $\begin{array}{c}95 \% \text { CI for } \\
\text { OR higher }\end{array}$ \\
\hline T/C \& G/A & 0.744 & 0.251 & 8.820 & 0.003 & 2.105 & 1.288 & 3.441 \\
T/C \& A/A & 0.820 & 1.091 & 0.564 & 0.453 & 0.440 & 0.052 & 3.741 \\
C/C \& G/A & 1.108 & 0.766 & 2.089 & 0.148 & 0.330 & 0.074 & 1.483 \\
C/C \& A/A & 1.847 & 0.555 & 11.082 & 0.001 & 6.343 & 2.138 & 18.821 \\
\hline
\end{tabular}

Note: The comparison was carried out among homozygotes for the major allele; CR — regression coefficient; SE — standard error; WS — Wald statistics; P — statistical significance; OR — odds ratio; CI — confidence interval. 


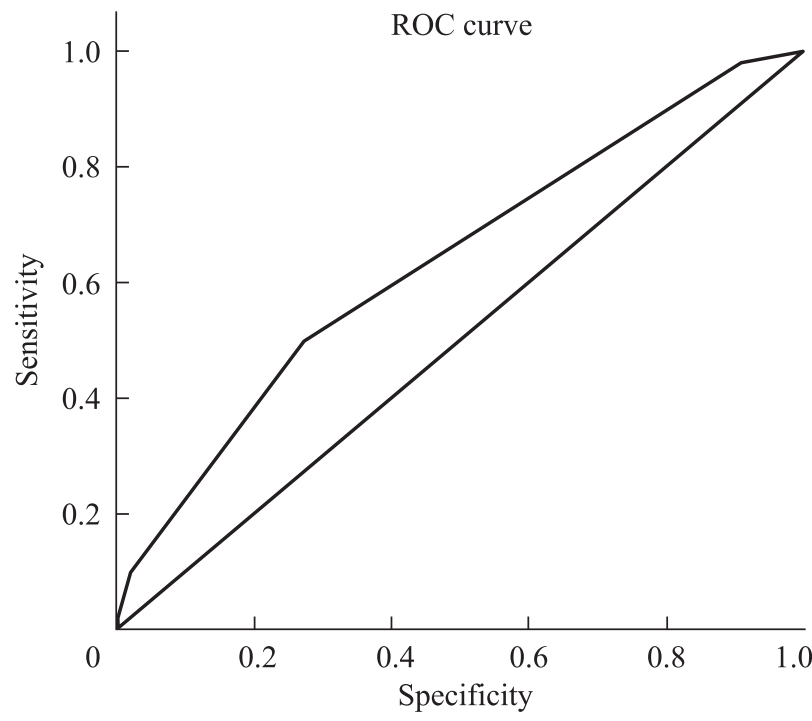

Fig. 6. Graphic representation of the relationship between sensitivity and specificity using ROC-curve

of the $M G P$ gene was modeled, using the binary logistic regression (Table 7). Analysis of the results showed that two heterozygotes and two homozygotes for the minor allele and homozygous for the major allele genotypes were associated with the risk of disease. Heterozygote genotype was associated with the increased risk of disease by 2.1 times and homozygote for the minor allele genotype - by 6.3 times.

Analyzing the ROC-curve that describes the link between the sensitivity and specificity of the model, we found out that the area under the curve (AUC) is $63 \%$, which proves satisfactory prognostic significance of the created model (Fig. 6).

To answer the question why MDR method chose two-component model as the best one, though Random Forest showed a greater number of predictors, the model was constructed once again using the Random Forest method that contained only polymorphisms rs1800801 and rs4236 of the MGP gene. The predictive ability of the model did not change. We had the same $68 \%$ predictive ability while analyzing all ten loci. It was the evidence that the rs1800801 and rs4236 loci were indeed statistically significant. All other predictors to the right of the dotted line - were important, but did not reach the level of statistical significance to affect considerably the ability of classification models.

\section{Conclusions}

There is a connection between ACS and polymorphic variants of the genes: MGP (rs1800801), VDR (rs1544410), GGCX (rs699664) and VKORC1 (rs23 59612). The risk of ACS in carriers of the minor allele $\mathrm{A} / \mathrm{A}$ (rs1800801) is 2.8 times higher; G/G (rs1544410) 2.1 times higher; A (rs699664) and C (rs2359612) twice higher than in the carriers of the major allele. The best classification model is a two-component model that includes polymorphisms rs1800801 and rs4236 of the MGP gene (predictive ability is $63 \%$ for MDR and 68 $\%$ for the Random forest method). The coincidence of similar orientation genotypes variants for chosen polymorphism was associated with the high risk of ACS: in heterozygotes it increased by 2.1 times, and homozygotes for the minor allele - by 6.3 times.

\section{REFERENCES}

1. Abedin M, Tintut Y, Demer LL. Vascular calcification: mechanisms and clinical ramifications. Arterioscler Thromb Vasc Biol. 2004;24(7):1161-70.

2. Atkinson J. Age-related medial elastocalcinosis in arteries: mechanisms, animal models, and physiological consequences. J Appl Physiol. 2008;105(5):1643-51.

3. Dao HH, Essalihi R, Bouvet C, Moreau P. Evolution and modulation of age-related medial elastocalcinosis: impact on large artery stiffness and isolated systolic hypertension. Cardiovasc Res. 2005;66(2):307-17.

4. Guzman RJ. Clinical, cellular, and molecular aspects of arterial calcification. J Vasc Surg. 2007;45 Suppl A:A57-63.

5. Lanzer $P$. Mönckeberg media calcinosis. $Z$ Kardiol. 1998;87(8):586-93.

6. Lehto S, Niskanen L, Suhonen M, Rönnemaa T, Laakso M. Medial artery calcification. A neglected harbinger of cardiovascular complications in non-insulin-dependent diabetes mellitus. Arterioscler Thromb Vasc Biol. 1996; 16 (8):978-83.

7. Wayhs $R$, Zelinger $A$, Raggi $P$. High coronary artery calcium scores pose an extremely elevated risk for hard events. $J \mathrm{Am}$ Coll Cardiol. 2002;39(2):225-30.

8. Garbuzova VYu, Ataman AV. Matrix Gla-protein and its role in vascular calcification. Int J Physiol Pathophysiol. 2012; 3(1):79-99.

9. Proudfoot D, Shanahan CM. Molecular mechanisms mediating vascular calcification: role of matrix Gla protein. Nephrology (Carlton). 2006;11(5):455-61.

10. Weissen-Plenz G, Nitschke Y, Rutsch F. Mechanisms of arterial calcification: spotlight on the inhibitors. Adv Clin Chem. 2008;46:263-93.

11. Shao JS, Cheng SL, Sadhu J, Towler DA. Inflammation and the osteogenic regulation of vascular calcification: a review and perspective. Hypertension. 2010;55(3):579-92. 
12. Garbuzova VYu, Gurianova VL, Stroy DA, Dosenko VE, Parkhomenko AN, Ataman AV. Association of matrix Gla protein gene allelic polymorphisms $\left(\mathrm{G}^{-7} \rightarrow \mathrm{A}, \mathrm{T}^{-138} \rightarrow \mathrm{C}\right.$ and $\mathrm{Thr}_{83} \rightarrow$ Ala) with acute coronary syndrome in the Ukrainian population. Exp Clin Cardiol. 2012; 17(1):30-33.

13. Ataman AV, Garbuzova VYu, Ataman YuA, Matlaj OI, Obukhova $O A$. Investigation of the MGP promoter and exon 4 polymorphisms in patients with ischemic stroke in the Ukrainian population. J Cell Mol Biol. 2012; 10(1):19-26.

14. Brancaccio D, Biondi ML, Gallieni $M$, et al. Matrix GLA protein gene polymorphisms: clinical correlates and cardiovascular mortality in chronic kidney disease patients. $\mathrm{Am} \mathrm{J}$ Nephrol. 2005;25(6):548-52.

15. Crosier MD, Booth SL, Peter I, et al. Matrix Gla protein polymorphisms are associated with coronary artery calcification in men. J Nutr Sci Vitaminol (Tokyo). 2009;55(1): 59-65.

16. Herrmann SM, Whatling $C$, Brand E, et al. Polymorphisms of the human matrix gla protein (MGP) gene, vascular calcification, and myocardial infarction. Arterioscler Thromb Vasc Biol. 2000;20(11):2386-93.

17. Kobayashi N, Kitazawa R, Maeda S, Schurgers L, Kitazawa $S$. T-138C polymorphism of matrix gla protein promoter alters its expression but is not directly associated with atherosclerotic vascular calcification. Kobe J Med Sci. 2004;50(34):69-81.

18. Taylor BC, Schreiner PJ, Doherty TM, Fornage M, Carr JJ, Sidney $S$. Matrix Gla protein and osteopontin genetic associations with coronary artery calcification and bone density: the CARDIA study. Hum Genet. 2005;116(6):525-8.

19. Kim JG, Ku SY, Lee DO, et al. Relationship of osteocalcin and matrix Gla protein gene polymorphisms to serum osteocalcin levels and bone mineral density in postmenopausal Korean women. Menopause. 2006;13(3):467-73.

20. Tsukamoto K, Orimo H, Hosoi T, et al. Association of bone mineral density with polymorphism of the human matrix Gla protein locus in elderly women. J Bone Miner Metab. 2000;18(1):27-30.

21. Gao B, Yasui T, Itoh Y, Tozawa K, Hayashi Y, Kohri K. A polymorphism of matrix Gla protein gene is associated with kidney stones. J Urol. 2007;177(6):2361-5.

22. Hirano H, Ezura $Y$, Ishiyama $N$, et al. Association of natural tooth loss with genetic variation at the human matrix Gla protein locus in elderly women. J Hum Genet. 2003; 48 (6):288-92.

23. Shaik AP, Jamil K. Individual susceptibility and genotoxicity in workers exposed to hazardous materials like lead. $J$ Hazard Mater. 2009;168(2-3):918-24.

24. Shaik AP, Jamil K. Polymorphisms in MGP gene and their association with lead toxicity. Toxicol Mech Methods. 2009;19(3):209-13.

25. Braunwald E, Antman EM, Beasley JW, et al. ACC/AHA guidelines for the management of patients with unstable angina and non-ST-segment elevation myocardial infarction: executive summary and recommendations. A report of the American College of Cardiology/American Heart Associa- tion task force on practice guidelines (committee on the management of patients with unstable angina). Circulation. 2000;102(10):1193-209.

26. Bertrand ME, Simoons ML, Fox KA, et al. Management of acute coronary syndromes in patients presenting without persistent ST-segment elevation. Eur Heart J. 2002;23(23): 1809-40.

27. Breiman L, Friedman JH, Olshen RA. Classification and regression trees. Belmont: C. A. «Wadsworth», 1984; 368 p.

28. Breiman L. Random Forests. Machine Learning. 2001; 45 (1):5-32.

29. Strobl C, Boulesteix AL, Kneib T, Augustin T, Zeileis A. Conditional variable importance for random forests. $B M C$ Bioinformatics. 2008;9:307.

30. Motsinger AA, Ritchie MD. Multifactor dimensionality reduction: an analysis strategy for modelling and detecting gene-gene interactions in human genetics and pharmacogenomics studies. Hum Genomics. 2006;2(5):318-28.

31. Ortlepp JR, Krantz C, Kimmel M, et al. Additive effects of the chemokine receptor 2, vitamin D receptor, interleukin-6 polymorphisms and cardiovascular risk factors on the prevalence of myocardial infarction in patients below 65 years. Int J Cardiol. 2005;105(1):90-5.

32. Shanker J, Maitra A, Arvind P, et al. Role of vitamin D levels and vitamin $\mathrm{D}$ receptor polymorphisms in relation to coronary artery disease: the Indian atherosclerosis research study. Coron Artery Dis. 2011;22(5):324-32.

33. Pan XM, Li DR, Yang L, et al. No association between vitamin D receptor polymorphisms and coronary artery disease in a Chinese population. DNA Cell Biol. 2009;28(10): 521-5.

34. Porojan M, Dumitraşcu DL. Genetic polymorphism of VKORC 1 and KLOTHO genes associated with atherosclerosis. Clujul. Medical. 2014; 85(4):533-6.

35. Wang $Y$, Zhang $W$, Zhang $Y$, et al. VKORCl haplotypes are associated with arterial vascular diseases (stroke, coronary heart disease, and aortic dissection). Circulation. 2006;113 (12):1615-21.

36. Hindorff LA, Heckbert SR, Smith N, Marciante KD, Psaty $B M$. Common VKORC1 variants are not associated with arterial or venous thrombosis. J Thromb Haemost. 2007; 5 (10):2025-7.

В. Ю. Гарбузова, Д. А. Строй,

В. Є. Досенко, О. А. Обухова, О. В. Атаман

\section{Асоціація алельних поліморфізмів генів системи матриксного Gla-протеїну з гострим коронарним синдромом в українській популяції}

Кальцифікація судинної стінки є несприятливим прогностичним фактором фатальних наслідків гострого коронарного синдрому (ГКС). Важливим захисним фактором судин від ектопічної кальцифікації є система матриксного Gla-протеїну, яка включає MGP, VDR, VKOR, GGCX, BMP-2. Поліморфізм генів, які кодують структуру даних білків, визначає їх активність і можливо впливає на інтенсивність кальцификации і наслідки 
ГКС. Мета. Проаналізувати зв'язок між ГКС і поліморфними варіантами генів: $M G P$ (rs1800802, rs1800801, rs4236), VDR (rs2228570, rs1544410, rs7975232, rs731236), GGCX (rs699664), VKORCl (rs2359612), BMP-2 (rs 2273073). Методи. Для генотипування була використана венозна кров 118 пацієнтів з ГКС і 234 здорових індивідуумів (контрольна група). Визначення поліморфізму генів системи матриксного Gla-протеїну проводили за допомогою методу полімеразної ланцюгової реакції з наступним аналізом довжини рестрикційних фрагментів при виявленні їх шляхом електрофорезу в агарозному гелі. Результати. Ризик ГКС у носіїв мінорного аллеля А/A (rs1800801) в 2,8 рази; G/G (rs1544410) в 2,1 рази; A (rs699664) і C (rs2359612) в 2 рази вище, ніж у носіїв основного аллеля. Кращою класифікаційної моделлю є двокомпонентна модель, яка включає в себе поліморфні варіанти (rs1800801, rs4236) гена MGP (прогностична здатність 63 \% за методом MDR i $68 \%$ за методом Random forest). Збіг в однієї особи подібних за спрямованістю варіантів генотипів за зазначеними поліморфізмами асоціюється зі збільшенням ризику ГКС: у гетерозигот за обома поліморфізмами він підвищується у 2,1 раза, а в гомозигот за мінорними алелями - у 6,3 раза. Висновки. Існує зв'язок між ОКС і деякими поліморфними варіантами генів системи матриксного Gla-протеїну: $M G P$ (rs1800801), VDR (rs1544410), GGCX (rs699664), $V K O R C 1$ (rs2359612). Це свідчить про великий ризик ускладнень у пацієнтів з ГКС, які мали генотипи А/A (rs1800801), G/G (rs1544410), A/A (rs 699664) and C/C (rs2359612).

Кл юч о в і сл о в а: гострий коронарний синдром, алельних поліморфізм, матриксний Gla-протеїн.

В. Ю. Гарбузова, Д. А. Строй,

В. Е. Досенко, О. А. Обухова, А. В. Атаман

Ассоциация аллельных полиморфизмов генов системы матриксного Gla-протеина с острым коронарным синдромом в украинской популяции

Кальцификация сосудистой стенки является неблагоприятным прогностическим фактором фатальных последствий острого ко- ронарного синдрома (ОКС). Важным защитным фактором сосудов от эктопической кальцификации является система матриксного Gla-протеина, которая включает MGP, VDR, VKOR, GGCX, BMP-2. Полиморфизм генов, которые кодируют структуру данных белков, определяет их активность и возможно влияет на интенсивность кальцификации и исход ОКС. Цель. Проанализировать связь между ОКС и полиморфными вариантами генов: $M G P(\mathrm{rs} 1800802, \mathrm{rs} 1800801, \mathrm{rs} 4236), V D R(\mathrm{rs} 2228570, \mathrm{rs} 1544410$, rs7975232, rs7 31236), GGCX (rs699664), VKORC1 (rs2359612), $B M P-2$ (rs2273 073). Методы. Для генотипирования была использована венозная кровь 118 пациентов с ОКС и 234 здоровых индивидуумов (контрольная группа). Определение полиморфизма генов системы матриксного Gla-протеина проводили с помощью метода полимеразной цепной реакции с последующим анализом длины рестрикционных фрагментов при выявлении их путем электрофореза в агарозном геле. Результаты. Риск ОКС у носителей минорного аллеля $\mathrm{A} / \mathrm{A}$ (rs180 0801) в 2,8 раза; $\mathrm{G} / \mathrm{G}(\mathrm{rs} 1544410)$ в 2,1 раза; A (rs699664) и C (rs2359612) в 2 раза выше, чем у носителей основного аллеля. Лучшей классификационной моделью является двухкомпонентная модель, которая включает полиморфные варианты (rs1800801, rs4236) гена $M G P$ (прогностическая способность 63 \% по методу MDR и 68 \% по методу Random forest). Совпадение у одного пациента сходных по направленности вариантов генотипа по указанным полиморфизмам ассоциируется с увеличением риска ОКС: у гетерозигот по обоим полиморфизм он повышается в 2,1 раза, а у гомозигот по минорным аллелям - в 6,3 раза. Выводы. Существует связь между ОКС и некоторыми полиморфными вариантами генов системы матриксного Gla-протеина: $M G P$ (rs1800801), VDR (rs1544410), GGCX (rs699 664), VKORC1 (rs2359612). Это свидетельствует о большом риске осложнений у пациентов с ОКС, которые имеют генотипы А/A (rs1800801), G/G (rs1544410), A/A (rs699664) and C/C (rs2359612).

Ключ е в ы е сл о в а: острый коронарный синдром, аллельный полиморфизм, матриксный Gla-протеин.

Received 20.09.2014 